\title{
STUDY ON MECHANICAL AND DURABILITY PROPERTIES OF MIXTURES WITH FLY ASH FROM HONGSA POWER PLANT
}

\author{
Nilankham Banchong ${ }^{1}$, Warangkana Saengsoy ${ }^{2}$, and Somnuk Tangtermsirikul ${ }^{3}$ \\ ${ }^{1}$ School of Civil Engineering and Technology, Sirindhorn International Institute of Technology, Thammasat \\ University, Pathum Thani, Thailand, Tel: (+66) 992614853, e-mail: molly.gday@ gmail.com \\ ${ }^{2}$ Construction and Maintenance Technology Research Center, School of Civil Engineering and Technology, \\ Sirindhorn International Institute of Technology, Thammasat University, Pathum Thani, Thailand, \\ Tel: (+66) 29869009 Ext. 3409, e-mail: warangkana@ @iit.tu.ac.th \\ ${ }^{3}$ School of Civil Engineering and Technology, Sirindhorn International Institute of Technology, Thammasat \\ University, Pathum Thani, Thailand, Tel: (+66) 29869009 Ext. 1908, e-mail: somnuk@ siit.tu.ac.th
}

Received Date: February 15, 2019; Revised Date: September 24, 2019; Acceptance Date: November 25, 2019

\begin{abstract}
The use of fly ash in concrete improves several characteristics of conventional cement-based pastes, mortars, and concrete such as reduces heat of hydration, increases strength in long-term and enhances durability. However, types and volume of fly ash affect behavior of resulting pastes, mortars and concrete. In this study, the characteristics of pastes, mortars, and concrete with $20 \%$ and 30\% binder replacement with a Hongsa fly ash from Laos (FAH3) and two fly ashes from Thailand (FAM and FAB) were studied. Further, mechanical and durability properties of Hongsa fly ash mortars and concrete are investigated through specific gravity, Blaine fineness, normal consistency, setting times, water requirement, strength index, slump and slump retention, compressive strength of concrete with a fixed slump, compressive strength of concrete with a fixed $\mathrm{w} / \mathrm{b}$ of 0.5 , semi-adiabatic temperature, total shrinkage, carbonation depth, $\mathrm{H}_{2} \mathrm{SO}_{4}$ acid resistance, rapid chloride penetration (RCP) and chloride distribution. The experimental results show that the Hongsa fly ash contains large amount of non-spherical particles with coarse cavities, leading to high surface area and high Blaine fineness value. Accordingly, Hongsa fly ash was found to have high water requirement. In comparison to the ordinary Portland cement type I (OPC) and Mae Moh fly ash (FAM), the Hongsa fly ash was found to generate lower heat. As a result, the Hongsa fly ash shows its potential in the application of mass concrete. Similarly, the Hongsa fly ash mortar exhibited the lowest carbonation depth when compared to the FAM and FAB mortars. In term of RCPT and chloride distribution test, the Hongsa fly ash concrete shows the lowest $\mathrm{Cl}^{-}$penetrability when compared with Portland cement type I (OPC) concrete, FAM and FAB concretes. Based on the experimental results, the Hongsa fly ash was found to be applicable in concrete works.
\end{abstract}

Keywords: Compressive strength, Durability, Fly ash, Hongsa power plant

\section{Introduction}

Hongsa power plant in Laos produces approximately 2 million tons of fly ash every year [1]. However, there is still no data of Hongsa fly ash's properties to make sure that the fly ash can be applied in concrete work. This research provides the first set of data for fly ash in Laos. Many previous researchers show that the use of fly ash in concrete provides several desirable characteristics such as improving concrete durability, reducing shrinkage, enhancing workability of the concrete [2]. Apart from the improvement of concrete characteristics, use of fly ash reduces the adverse impact on the environment due to reduction of cement consumption as well as disposal of the fly ash. Effective utilization of fly ash in concrete reduces the production of Portland cement, which emits a significant amount of carbon dioxide into the environment [3]. Properties of fly ash are governed by various 
parameters such as type of coal, process of burning and collecting [4]. Therefore, properties of fly ashes even from the same power plant may vary. Depending on the types and characteristics of fly ashes, their effects on concrete are different. As a result, before using a fly ash in the concrete mix, an in-depth study of its characteristics is required.

In this paper, some basic properties of three fly ashes (two from Thailand and one from Laos), durability and other properties of mortars and concrete incorporating the fly ashes were studied. The studied basic properties include normal consistency, setting times, water requirement, strength index of mortars at 3, 7, 28 and 91 days. The other studied properties are slump and slump retention, compressive strength of concrete at 3, 7, 28 and 91 days, semi-adiabatic temperature as well as durability properties such as total shrinkage, carbonation depth, $\mathrm{H}_{2} \mathrm{SO}_{4}$ acid resistance, rapid chloride penetration (RCP) and chloride distribution.

\section{Experimental Program}

\section{Material Properties}

An ordinary Portland cement type I (OPC), a Hongsa fly ash from Hongsa power plant in Laos (FAH3) and two Thai fly ashes from Mae Moh and BLCP power plants (FAM and FAB), respectively were used in the experiment. All the fly ash samples were collected from their respective power plant in March 2017. Their physical and chemical properties are shown in Table 1. Particle size distributions of the OPC, FAM, FAB, and FAH3 were obtained by using laser diffraction particle size analyzer "Malvern Mastersizer 2000" and are presented in Figure 1.

Table 1. Chemical Compositions and Physical Properties of Cement and Fly Ashes

\begin{tabular}{|c|c|c|c|c|}
\hline Component & Cement & FAM & FAH3 & FAB \\
\hline $\mathrm{SiO}_{2}(\%)$ & 19.70 & 34.50 & 48.68 & 64.45 \\
\hline $\mathrm{Al}_{2} \mathrm{O}_{3}(\%)$ & 5.19 & 17.91 & 30.44 & 20.58 \\
\hline $\mathrm{Fe}_{2} \mathrm{O}_{3}(\%)$ & 3.34 & 13.73 & 5.97 & 3.76 \\
\hline $\mathrm{CaO}(\%)$ & 64.80 & 20.76 & 5.85 & 2.55 \\
\hline $\operatorname{MgO}(\%)$ & 1.20 & 3.00 & 2.59 & 0.97 \\
\hline $\mathrm{SO}_{3}(\%)$ & 2.54 & 3.80 & 0.44 & 0.18 \\
\hline $\mathrm{Na}_{2} \mathrm{O}(\%)$ & 0.16 & 1.78 & 0.43 & 0.43 \\
\hline $\mathrm{K}_{2} \mathrm{O}(\%)$ & 0.44 & 2.13 & 3.44 & 1.51 \\
\hline LOI $(\%)$ & 2.10 & 1.26 & 0.89 & 4.01 \\
\hline Free lime $(\%)$ & - & 2.36 & 0.45 & 0.03 \\
\hline Amorphous content (\%) & - & 87.32 & 83.67 & 75.79 \\
\hline Specific gravity & 3.15 & 2.22 & 1.93 & 2.07 \\
\hline Blaine fineness $\left(\mathrm{cm}^{2} / \mathrm{g}\right)$ & 3010 & 1922 & 2709 & 2212 \\
\hline
\end{tabular}

Table 1 shows chemical compositions and physical properties of all tested binders. Classification of the tested fly ashes as per TIS 2135 [5] and ASTM C618 [6] is presented in Table 2.

Limestone coarse aggregate and river sand fine aggregate were used as per the recommendations from ASTM C33 [7]. Limestone with a maximum size of $25 \mathrm{~mm}$ with continuous gradation and specific gravity of 2.75 was used as the coarse aggregate. Regarding the fine aggregate, river sand having F.M of 2.80 was used. 


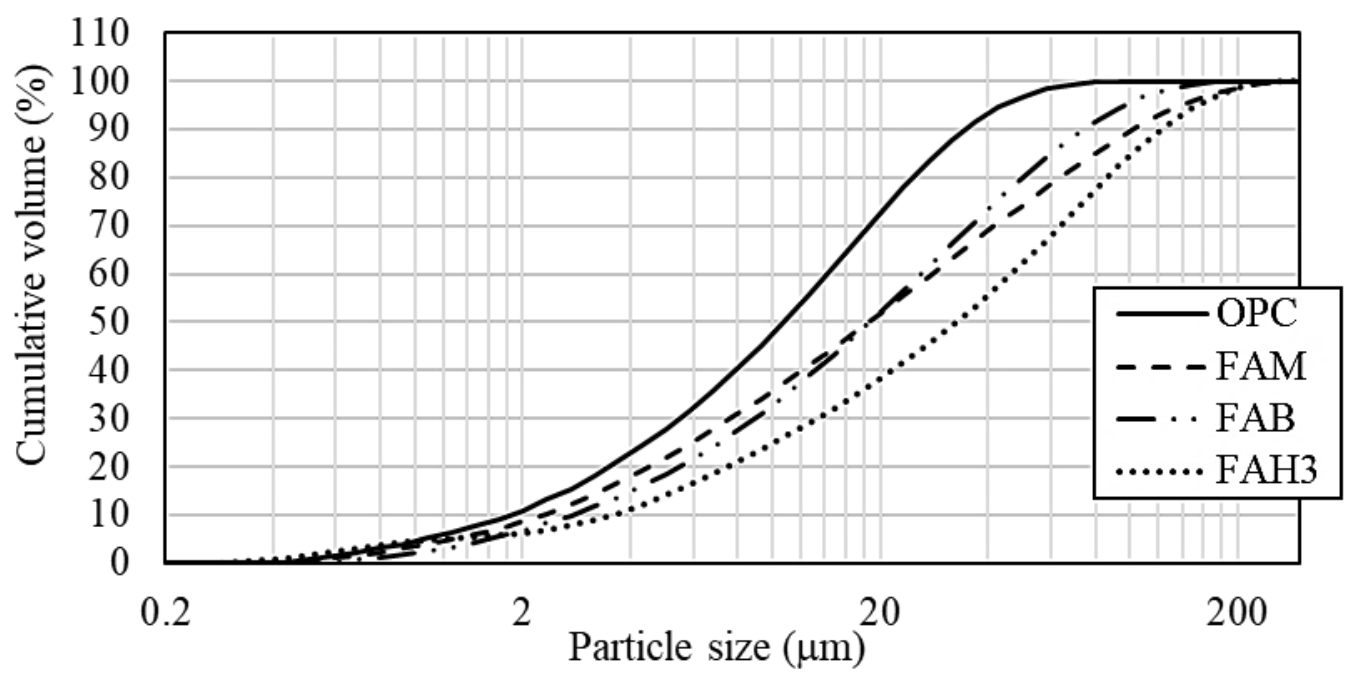

Figure 1. Particle size distribution of OPC, FAM, FAB and FAH3 determined by laser diffractometry

Table 2. Fly Ash Classifications (Based on Chemical Composition)

\begin{tabular}{lcc}
\hline Fly Ash & \multicolumn{2}{c}{ Class based on Standard } \\
\cline { 2 - 3 } & TIS 2135 & ASTM C618 \\
\hline FAM & $2 \mathrm{~b}$ & $\mathrm{C}$ \\
FAH3 & $2 \mathrm{a}$ & $\mathrm{F}$ \\
FAB & $2 \mathrm{a}$ & $\mathrm{F}$ \\
\hline
\end{tabular}

The SEM pictures of FAM, FAB and FAH3 are illustrated in Figures 2, 3 and 4. The SEM pictures show that FAH3 is almost non-spherical in shape with coarse cavities which make them porous and have high surface area and so high Blaine fineness. FAB also contains many non-spherical particles. On the other hand, FAM is spherical in shape.

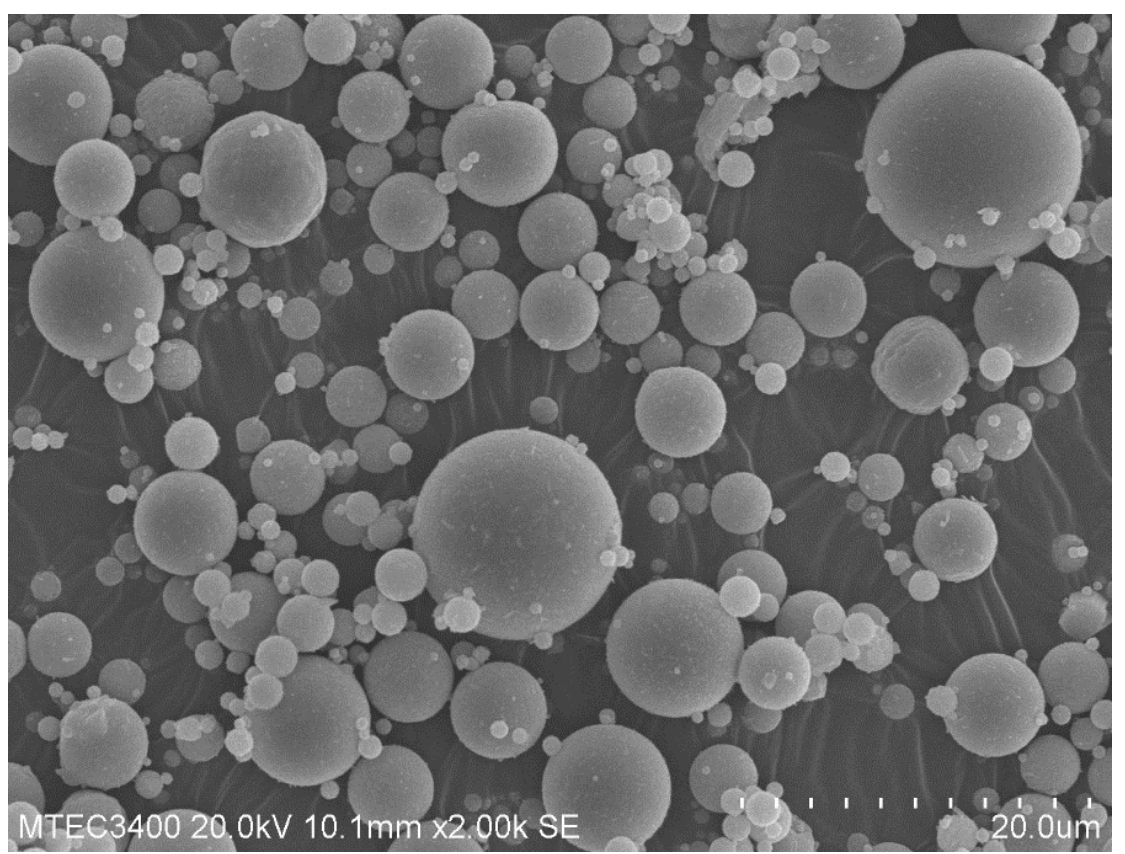

Figure 2. SEM image of Mae Moh fly ash (FAM) 


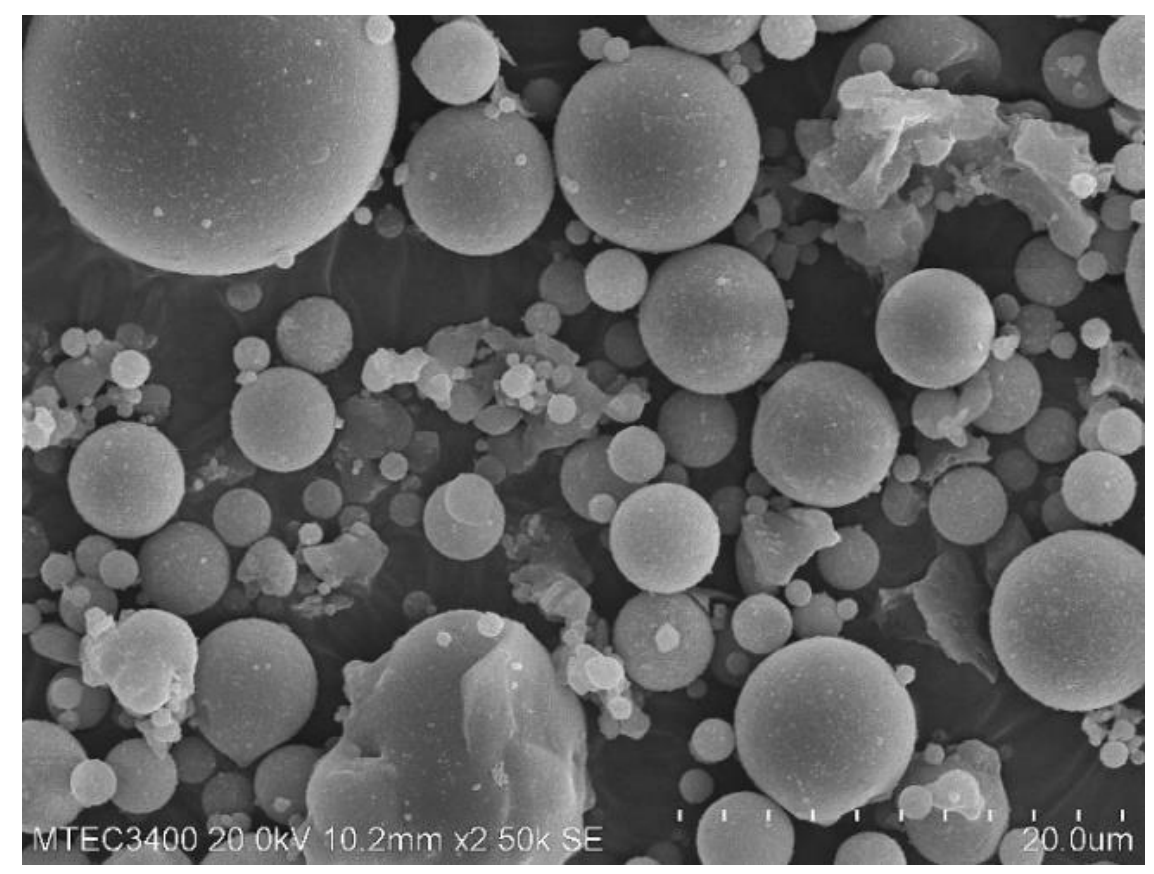

Figure 3. SEM image of BLCP fly ash (FAB)

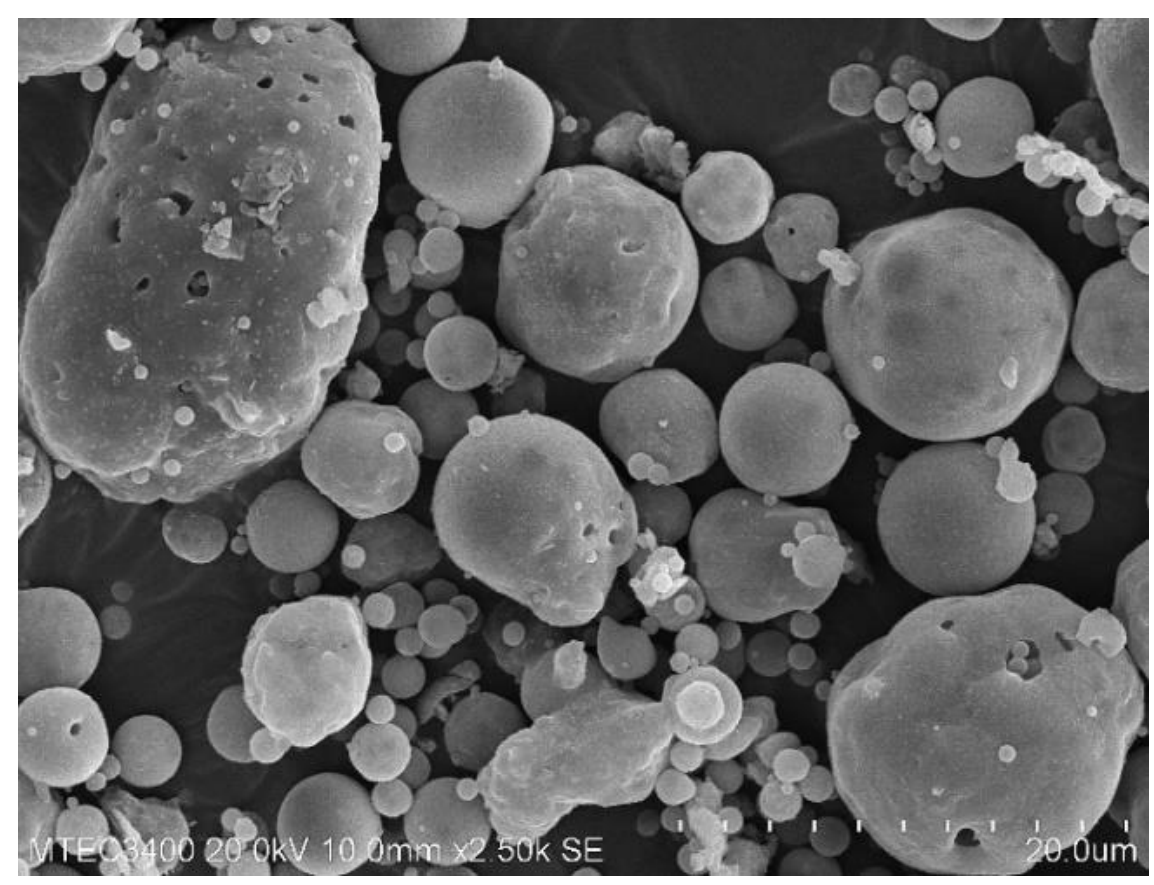

Figure 4. SEM image of Hongsa fly ash (FAH3)

\section{Experiments}

Some of the necessary basic properties of FAH3, FAB and FAM were tested. Normal consistency and setting times were determined according to ASTM C187 [8] and ASTM C191 [9], respectively. Water requirement and strength index were tested as per ASTM C311 [10]. The mix proportions were designed by replacing $20 \%$ by weight of total binder with each type of fly ash according to the ASTM standards $[8,9,10]$. Fly ash is normally used in concrete at the replacement ranges of $15 \%$ to $35 \%$ by weight of total cementitious materials. In this study, the fly ash replacement of $30 \%$ was used for testing mechanical and durability properties of mortars and concrete as the $30 \%$ replacement is normally specified as the 
maximum limit of replacement in various standards such as ACI 211.1 and ACI 232.2R [11, 12]. The water to binder ratio $(\mathrm{w} / \mathrm{b})$ of 0.5 was used for all tested properties except for the $\mathrm{H}_{2} \mathrm{SO}_{4}$ acid resistance. The lower w/b of 0.45 was used for testing the $\mathrm{H}_{2} \mathrm{SO}_{4}$ acid resistance in order to accelerate the deterioration of the tested specimens in acid solution. It was reported in the literature that specimens with a relatively lower w/b ratio showed higher degradation with a sulfuric acid attack than those with a higher w/b ratio [13]. Mortars were prepared with a sand to binder ratio of 2.75 by weight. Details of mix proportions and sizes of the specimen of pastes, mortars and concrete are presented in Table 3.

Table 3. Mix Proportions and Specimen Sizes

\begin{tabular}{lcccc}
\hline \multicolumn{1}{c}{ Test Items } & Type & $\begin{array}{c}\text { Dimension of } \\
\text { Specimen }\end{array}$ & $\begin{array}{c}\text { Fly Ash } \\
\text { Replacement } \\
\text { Ratio }\end{array}$ & w/b \\
\hline Normal consistency & Paste & $\varnothing 6$ top, $\varnothing 7 \mathrm{base} \times 4 \mathrm{~cm}$ & 0.2 & $\mathrm{NM}$ \\
Setting times & Paste & $\varnothing 6$ top, $\varnothing 7 \mathrm{base} \times 4 \mathrm{~cm}$ & 0.2 & $\mathrm{NM}$ \\
Water requirement & Mortar & - & 0.2 & WR \\
Strength index & Mortar & $5 \times 5 \times 5 \mathrm{~cm}$ & 0.2 & WR \\
Compressive strength & Concrete & $10 \times 10 \times 10 \mathrm{~cm}$ & 0.3 & WS \\
Compressive strength & Concrete & $10 \times 10 \times 10 \mathrm{~cm}$ & 0.3 & 0.5 \\
Slump \& slump retention & Concrete & - & 0.3 & WS \\
Semi-adiabatic temperature & Concrete & $40 \times 40 \times 40 \mathrm{~cm}$ & 0.3 & 0.5 \\
Total shrinkage & Mortar & $25 \times 25 \times 285 \mathrm{~mm}$ & 0.3 & 0.5 \\
Carbonation depth & Mortar & $10 \times 10 \times 10 \mathrm{~cm}$ & 0.3 & 0.5 \\
$\mathrm{H}_{2}$ SO 4 acid resistance & Mortar & $5 \times 5 \times 5 \mathrm{~cm}$ & 0.3 & 0.45 \\
RCPT & Concrete & $\varnothing 10 \times 20 \mathrm{~cm}$ & 0.3 & 0.5 \\
Chloride distribution & Concrete & $10 \times 10 \times 10 \mathrm{~cm}$ & 0.3 & 0.5 \\
\hline
\end{tabular}

Remark: $\mathrm{NM}=$ water to binder ratio that achieves normal consistency, $\mathrm{WR}=$ water to binder ratio that achieves a flow of $110 \pm 5 \%$, WS = water to binder ratio that achieves a slump of $7 \mathrm{~cm}$.

Slump and slump retention as well as compressive strength were measured in the laboratory according to ASTM C143 [14] and ASTM C39 [15], respectively. Semi-adiabatic temperature of fly ash concrete was tested following Viet et al. [16]. The cube plywood molds with a size of $50 \times 50 \times 50 \mathrm{~cm}$ containing insulation foam with a thickness of $5 \mathrm{~cm}$ at all sides were used to cast concrete specimens with a size of $40 \times 40 \times 40 \mathrm{~cm}$. Thermocouples were installed at the center of the specimens and connected to a data logger to measure the temperature rise of the concrete specimen at every $15 \mathrm{~min}$ interval. Compressive strength of concrete having $30 \%$ fly ash replacement with a control initial slump of $7 \mathrm{~cm}$ and a fixed w/b of 0.5 was tested. The details of the mix proportions of the tested concrete samples are shown in Table 4.

Total shrinkage, RCP, chloride distribution tests were carried out according to ASTM C157 [17], ASTM C1202 [18] and ASTM C1152 [19], respectively. As suggested by Kaewmanee et al. [20], accelerated carbonation test was conducted to accelerate the rate of carbonation. In this test, three specimens per mixture were cast. Before exposure to the carbonation environment, the specimens were cured in water for 7 days. $\mathrm{A} \mathrm{CO}_{2}$ concentration of $4 \%(40,000 \mathrm{ppm})$, a temperature of $40 \pm 2^{\circ} \mathrm{C}$ and a relative humidity of $50 \pm 5 \%$ were maintained in the carbonation chamber. The samples were measured the carbonation depth at 28 and 56 days after carbonation exposure by cutting the specimen into half and then sprayed $1 \%$ phenolphthalein solution on the cut surface. $\mathrm{H}_{2} \mathrm{SO}_{4}$ acid resistance by weight loss was tested following Sirisawat et al. [21]. The experiment was conducted by molding 3 mortar samples per mixture. The specimens were cured in water for 
28 days. The initial weights of the specimens were measured at 28 days after taking out of water. After that the specimens were exposed to $\mathrm{H}_{2} \mathrm{SO}_{4}$ solution ( $\mathrm{pH} 1$ ). The weight losses of the surface dried specimens were examined every 7 days until 150 days.

Thermogravimetric analysis (TGA) of hydrated cement pastes with a fly ash replacement of 30\% was tested at the age of 7 days. The $10-20 \mathrm{mg}$ of the powdered samples were tested by monitoring the weight while heating up from 30 to $950^{\circ} \mathrm{C}$ at $10^{\circ} \mathrm{C} / \mathrm{min}$, in the TGA/DSC $3+\mathrm{HT} / 1600$ instrument. The amount of calcium hydroxide $(\mathrm{CH})$ is expressed as a percentage of the dry sample weight at $470^{\circ} \mathrm{C}\left(\mathrm{W}_{470}\right)[22]$ as shown in Equation (1):

$$
\mathrm{CH}=\left(\frac{\left(\mathrm{W}_{410}-\mathrm{W}_{470}\right)}{\mathrm{W}_{470}} \times \frac{74}{18}\right) \times 100(\%)
$$

Where, $\quad \mathrm{CH}=$ Calcium hydroxide content $(\%)$.

$\mathrm{W}_{410}=$ Weight of dry sample at $410^{\circ} \mathrm{C}(\mathrm{g})$.

$\mathrm{W}_{470}=$ Weight of dry sample at $470^{\circ} \mathrm{C}(\mathrm{g})$.

$74=$ Molar mass of $\mathrm{Ca}(\mathrm{OH})_{2}$.

$18=$ Molar mass of $\mathrm{H}_{2} \mathrm{O}$.

Table 4. Mix Proportions of the Tested Concrete

\begin{tabular}{|c|c|c|c|c|c|c|c|}
\hline \multirow{2}{*}{ Mix ID } & \multicolumn{2}{|c|}{ Binder $\left(\mathrm{kg} / \mathrm{m}^{3}\right)$} & \multirow{2}{*}{$\begin{array}{c}\text { Fine } \\
\text { Aggregate } \\
\left(\mathrm{kg} / \mathbf{m}^{3}\right)\end{array}$} & \multirow{2}{*}{$\begin{array}{c}\text { Coarse } \\
\text { Aggregate } \\
\left(\mathrm{kg} / \mathrm{m}^{3}\right)\end{array}$} & \multirow{2}{*}{$\begin{array}{c}\text { Water } \\
\left(\mathrm{kg} / \mathrm{m}^{3}\right)\end{array}$} & \multirow{2}{*}{$\mathbf{w} / \mathbf{b}$} & \multirow{2}{*}{$\begin{array}{c}\text { Slump } \\
(\mathrm{cm})\end{array}$} \\
\hline & OPC & Fly Ash & & & & & \\
\hline OPC-S & 363.39 & 0 & 817.85 & 1051.83 & 167.94 & 0.5 & 7 \\
\hline FAM-S & 257.56 & 110.38 & 817.85 & 1051.83 & 151.82 & 0.45 & 7 \\
\hline FAH3-S & 224.73 & 96.31 & 815.12 & 1054.46 & 159.71 & 0.54 & 7 \\
\hline FAB-S & 237.06 & 101.60 & 815.12 & 1051.30 & 162.22 & 0.51 & 7 \\
\hline OPC-W & 363.39 & 0 & 814.47 & 1053.09 & 170.05 & 0.5 & 10 \\
\hline FAM-W & 242.54 & 103.94 & 814.47 & 1054.64 & 160.23 & 0.5 & 12 \\
\hline FAH3-W & 234.89 & 100.67 & 816.56 & 1053.62 & 153.52 & 0.5 & 4 \\
\hline FAB-W & 239.80 & 102.77 & 814.47 & 1052.88 & 159.85 & 0.5 & 7.5 \\
\hline
\end{tabular}

Remark: $-\mathrm{S}=$ control initial slump of $7 \mathrm{~cm},-\mathrm{W}=$ control water to binder ratio at $0.5, \mathrm{w} / \mathrm{b}=$ water to binder ratio.

\section{Results and Discussions}

\section{Basic Properties}

The results of normal consistency, setting times, water requirement and strength index of the tested mixtures made with fly ashes are shown in Figures 5, 6, 7 and 8, respectively.

It was found that FAM showed the lowest normal consistency and water requirement (see Figure 5 and Figure 7, respectively) due to its spherical and non-porous particle characteristics [23]. On the other hand, among all tested fly ashes, FAH3 exhibited the highest water requirement and normal consistency due to its porous and non-spherical nature together with largest particle size [24].

The initial and final setting times of all types of fly ash mixtures were longer than those of the reference cement mixture. Setting times depend partly on $\mathrm{CaO}$ content of the fly ash. In general, a fly ash that has low $\mathrm{CaO}$ content prolongs setting times of the mixture when compared to a high $\mathrm{CaO}$ fly ash [20]. So, FAM which is a high $\mathrm{CaO}$ fly ash sets faster than the rest of the fly ashes, which contain lower $\mathrm{CaO}$ contents. Furthermore, $\mathrm{FAH} 3$ has the highest normal consistency so the setting times of FAH3 is the longest [24] (see Figure 6). 


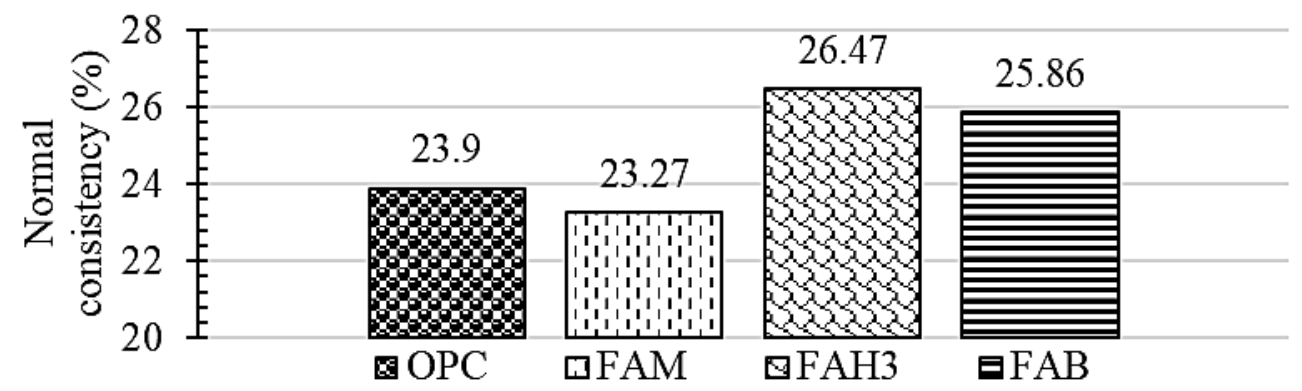

Figure 5. Normal consistency of the tested pastes

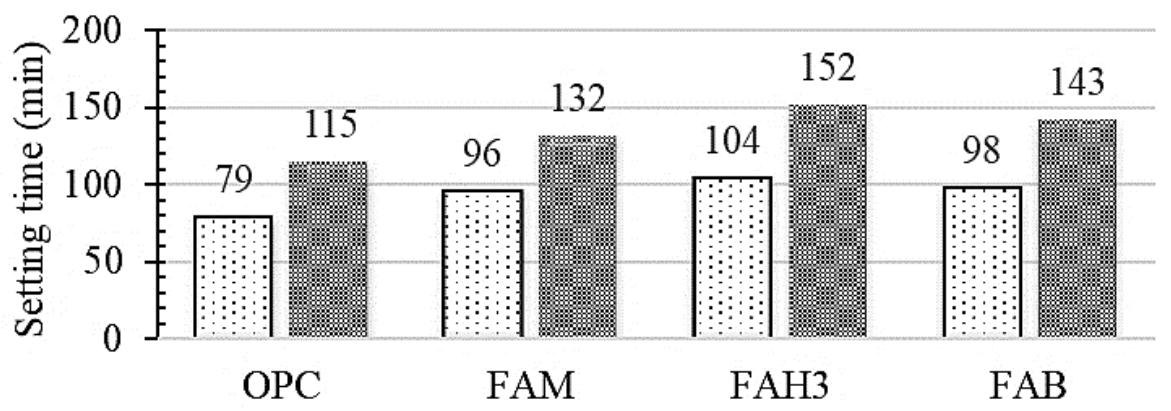

QInitial setting time (min) : Final setting time (min)

Figure 6. Setting times of the tested pastes

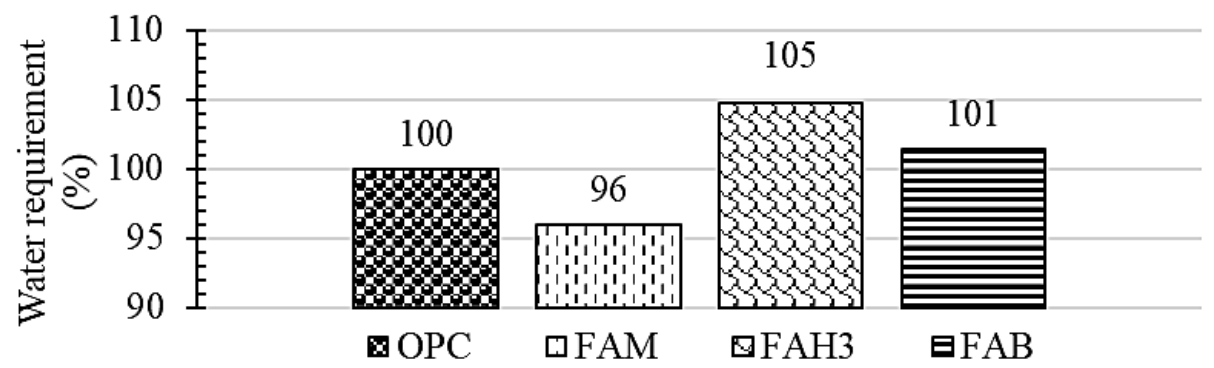

Figure 7. Water requirement of the tested mortars

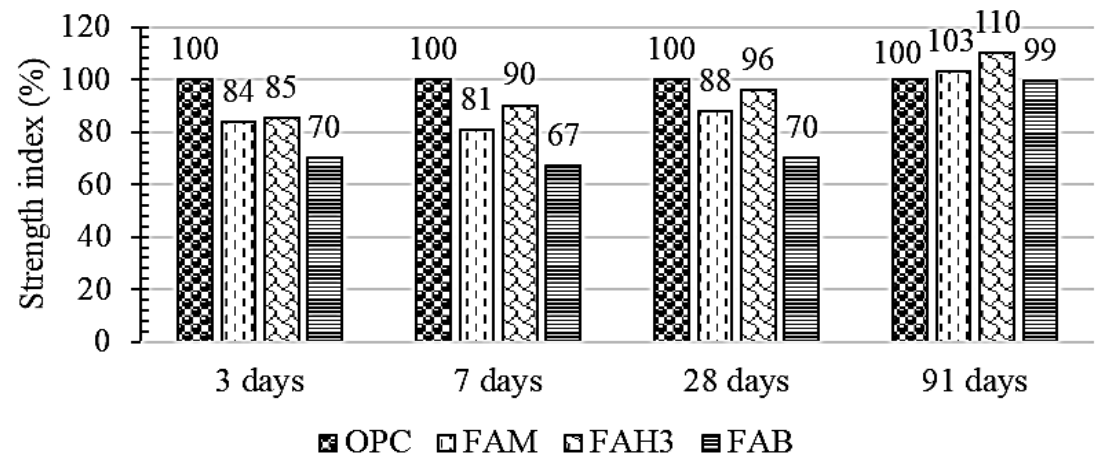

Figure 8. Strength index of the tested mortars

The strength index results show that fly ash mixture with FAH3 has the highest strength index, probably due to the highest surface area and high amorphous content (see Table 1), followed by FAM and FAB. The FAM mixture has higher strength than the FAB mixture especially at the early ages, mainly due to higher $\mathrm{CaO}$ and amorphous contents [25] (see Figure 8 and Table 1). 


\section{Concrete Properties}

The results of semi-adiabatic temperature, slump and slump retention, compressive strength at a fixed slump of $7 \mathrm{~cm}$ as well as compressive strength of mixtures with a fly ash replacement percentage of $30 \%$ and w/b of 0.5 are illustrated in Figures 9, 10, 11 and 12, respectively.

The semi-adiabatic temperature results are shown in Figure 9. The values of semiadiabatic temperature of the specimens were in the order of OPC, FAM, FAH3 and FAB (from maximum to minimum). In regard to chemical composition, heat generation in the concrete mainly depends on the amount of $\mathrm{CaO}$. Peak temperature, $\mathrm{CaO}$ content, Blaine fineness of the OPC and fly ashes are presented in Table 5, which shows that high $\mathrm{CaO}$ fly ash leads to high peak temperature [26].

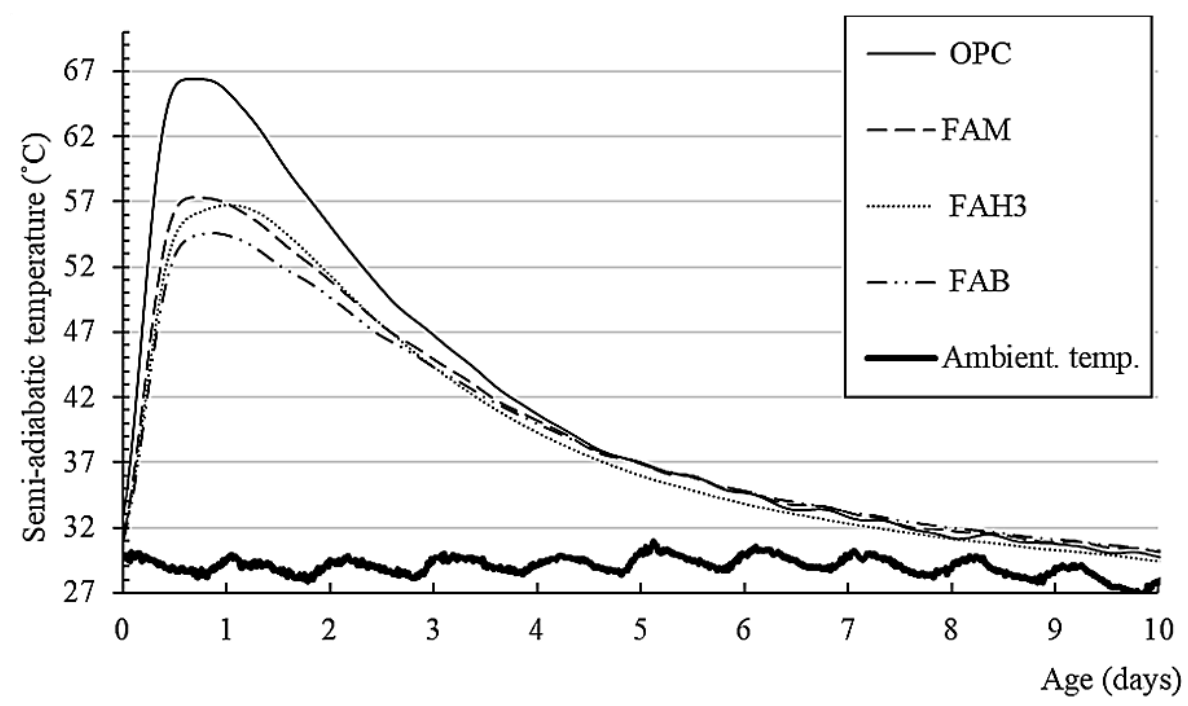

Figure 9. Semi-adiabatic temperature of the tested concrete mixtures

Table 5. Relationship between $\mathrm{CaO}$ Content, Blaine Fineness and Peak Temperature

\begin{tabular}{cccc}
\hline Samples & Peak Temp. $\left({ }^{\circ} \mathbf{C}\right)$ & CaO (\%) & Blaine Fineness $\left(\mathbf{c m}^{\mathbf{2}} / \mathbf{g}\right)$ \\
\hline OPC & 66.46 & 64.80 & 3010 \\
FAM & 57.30 & 20.76 & 1922 \\
FAH3 & 56.72 & 5.85 & 2709 \\
FAB & 54.59 & 2.55 & 2212 \\
\hline
\end{tabular}

Among the studied fly ash and OPC concrete mixtures with a control slump, Figure 10 demonstrates that the workability of FAH3 is excellent. Its slump can be retained beyond $1 \mathrm{~cm}$ until $150 \mathrm{~min}$. This behavior of FAH3 is consistent with the longest setting times when compared with FAM and FAB fly ashes (see Figure 6). FAM that has spherical shape also performs well for workability.

Figure 11 presents the compressive strength of the tested specimens. All of the tested specimens had the same mix proportion as those tested for slump and slump retention (see Table 4). All tested mixtures were prepared to have an equivalent initial slump of $7 \mathrm{~cm}$. Among all fly ash mixtures, the compressive strength of FAH3 was found to be equivalent or just slightly higher than that of FAM. The compressive strength of FAH3 is slightly higher than that of the FAM though the w/b of the FAH3 mixture is higher. This is probably due to the higher specific surface area of the FAH3 fly ash, which can accelerate the reaction of the FAH3 fly ash when compared with the FAM fly ash. Further, it is worth noting that the trend of compressive strength of concrete is similar to strength index of mortars. 


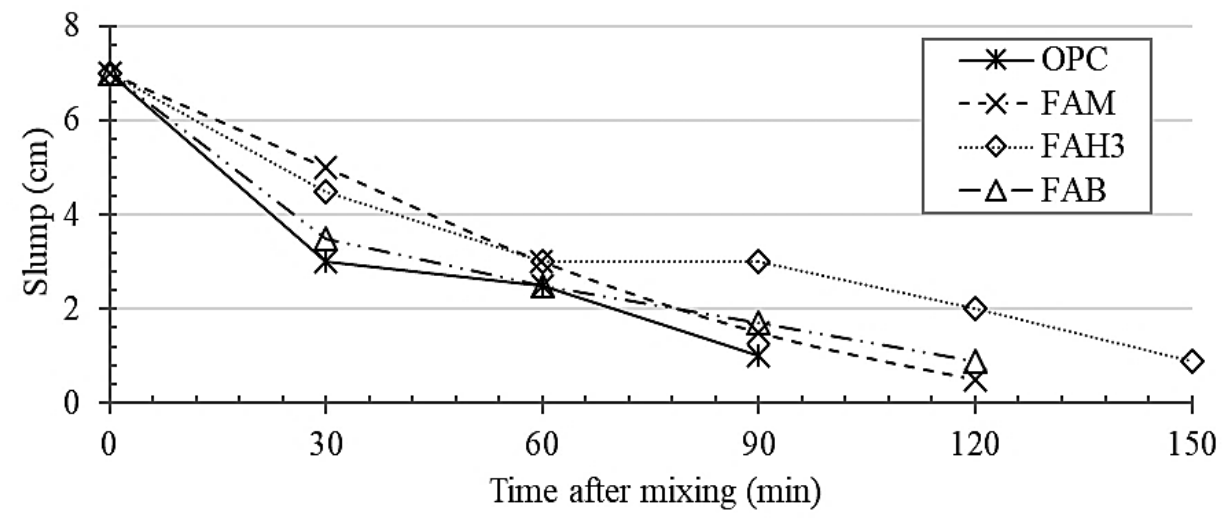

Figure 10. Slump and slump retention of mixtures with a control slump of $7 \mathrm{~cm}$

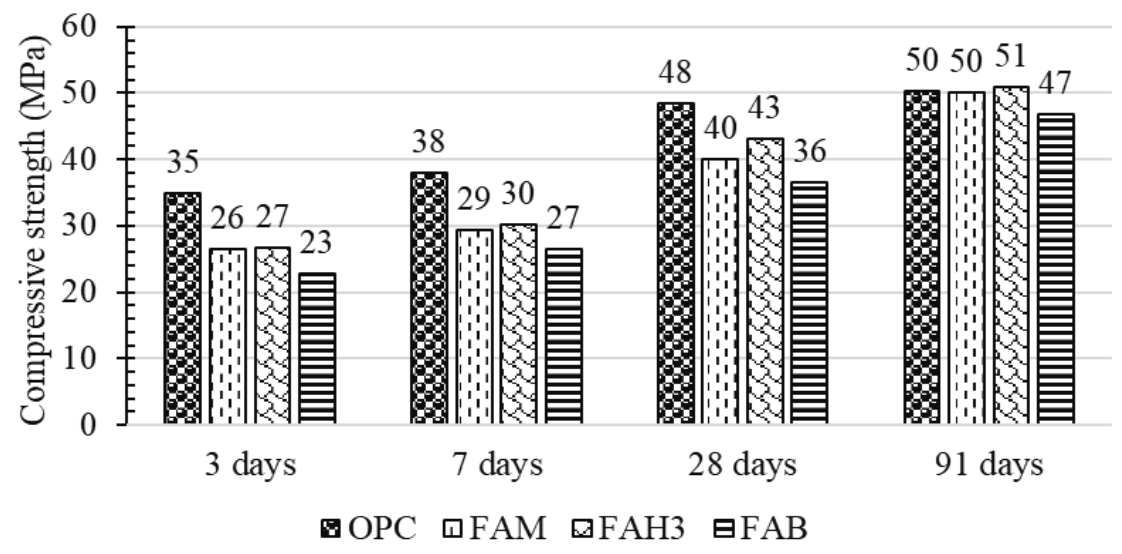

Figure 11. Compressive strength of concrete with a fixed slump of $7 \mathrm{~cm}$

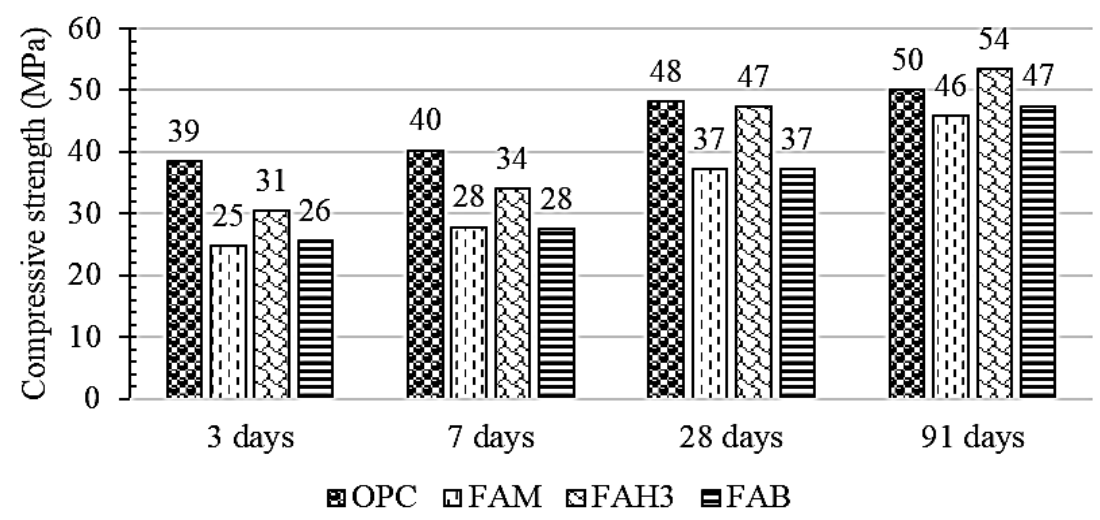

Figure 12. Compressive strength of concrete mixtures with a fly ash ratio of $30 \%$ and a fixed $\mathrm{w} / \mathrm{b}$ of 0.5

Figure 12 shows the compressive strength of concrete with $30 \%$ fly ash replacement with a fixed water to binder of 0.5 . The tested mixtures have the same mix proportions as those tested for semi-adiabatic temperature (see Table 4). All the mixtures have the same water to binder ratio of 0.5 . The FAH3 mixture shows the highest compressive strength due to the high specific surface area (Blaine fineness) and high amorphous content of the FAH3 fly ash. 


\section{Durability Properties}

All the fly ash mixtures show lower total shrinkage than the OPC mixture (see Figure 13). The mixtures that show from minimum to maximum shrinkage are FAM, FAH3, FAB and OPC. However, the mixtures of FAH3, FAB and OPC present not much difference in total shrinkage. The FAM mixture demonstrates slightly lower shrinkage than the other mixtures due to the higher contents of $\mathrm{CaO}$ and $\mathrm{SO}_{3}$ in $\mathrm{FAM}$ which can induce expansion from ettringite formation, so compensate the total shrinkage. According to a previous study of Chatchawan [27], measuring ettringite and portlandite contents of pastes containing high and low $\mathrm{CaO}$ fly ash at the age of 7 days, the high $\mathrm{CaO}$ fly ash paste produced higher amount of ettringite and portlandite than the low $\mathrm{CaO}$ fly ash paste (see Table 6). For clearly seeing the effect of induced expansion of high $\mathrm{CaO}$ fly ash mixture by ettringite formation and portlandite, the result of expansion at the end of water curing (7 days) of all tested fly ash mixtures is plotted in Figure 14. It can be seen from Figure 14 that the FAM mixture shows the largest expansion at the end of water curing when compared to all other fly ash mixtures. Moreover, FAH3 mixture shows slightly lower shrinkage than the FAB mixture, which is mainly due to the higher amorphous content of the FAH3. The higher amorphous content generates smaller pores leading to lower drying shrinkage [25, 28].

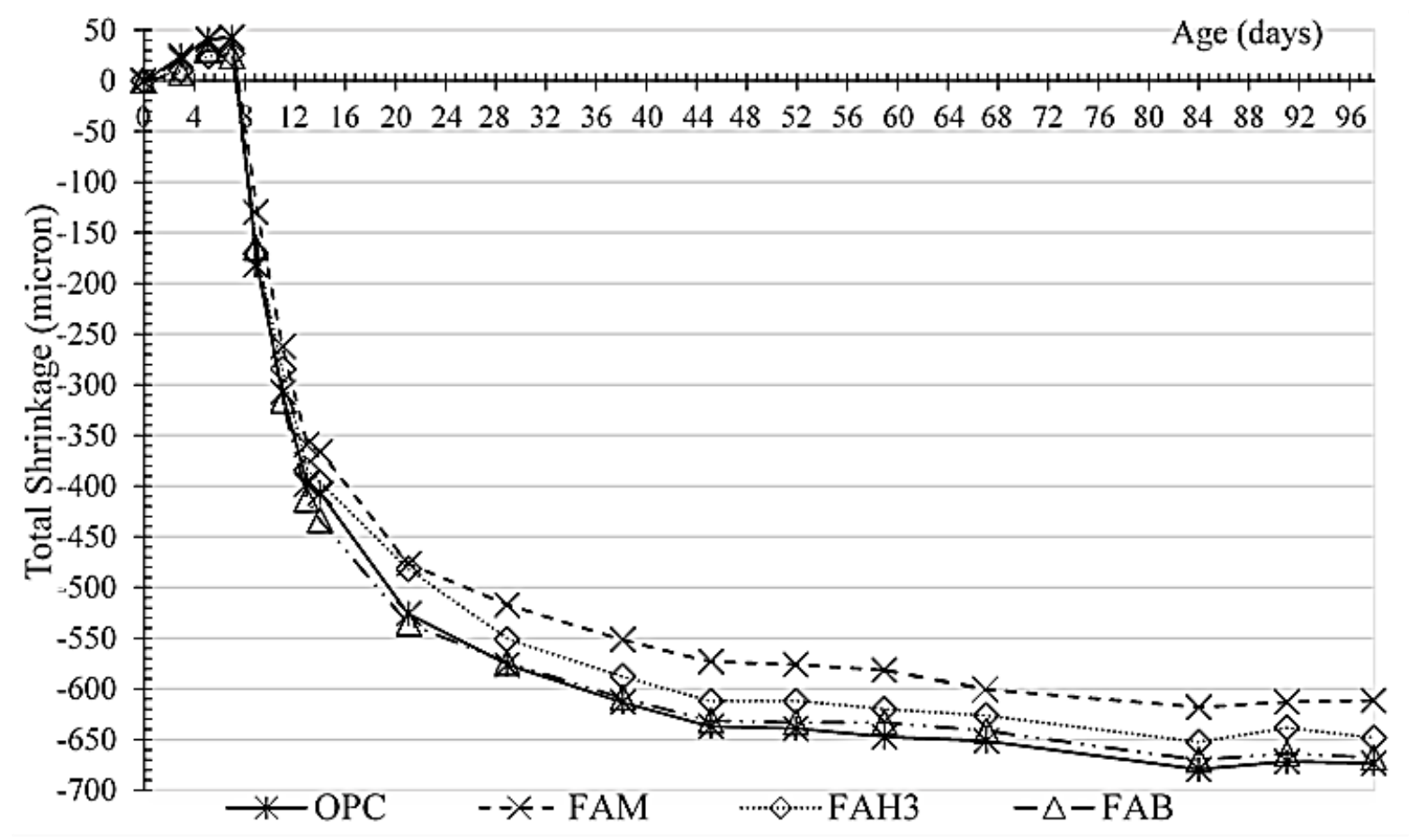

Figure 13. Total shrinkage of the tested mortars

Table 6. Ettringite Content of Paste at 7 days, Chatchawan [27]

$\begin{array}{lll}\text { Hydration Products (\%) High } \mathrm{CaO} & \text { Low } \mathrm{CaO}\end{array}$

\begin{tabular}{lcc}
\hline Ettringite Content & 1.656 & 0.000 \\
Portlandite & 10.140 & 9.084 \\
\hline
\end{tabular}




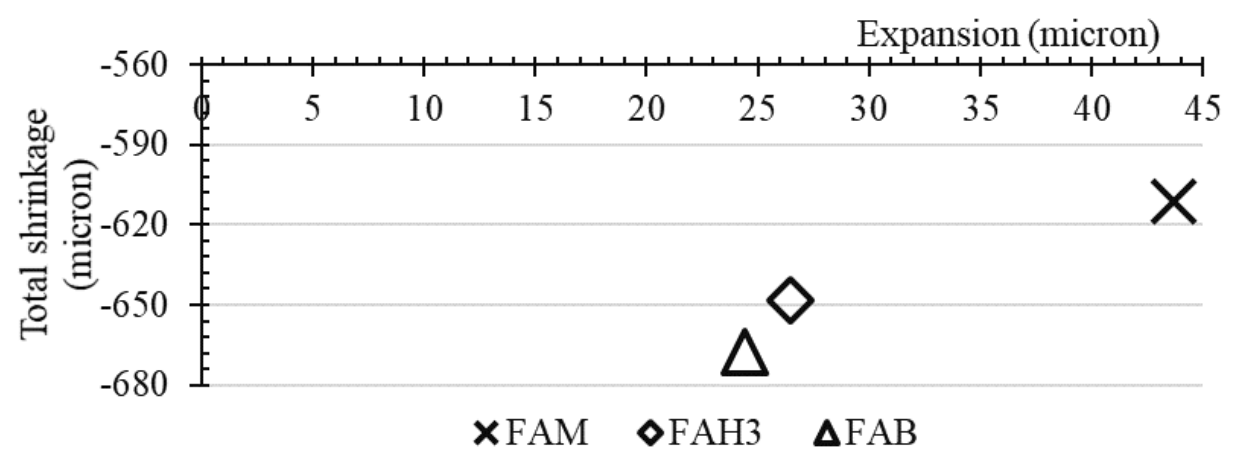

Figure 14. Expansion at 7 days in water curing and the total shrinkage at 98 days of the tested mortars

Carbonation test results are presented in Figure 15. Figure 15 shows that OPC mixture is the best with respect to carbonation resistance when compared to fly ash mixtures. Among the fly ash mixes, FAH3 had the smallest carbonation depth followed by FAM, and FAB. As per Khunthongkeaw et al. [29], the high $\mathrm{CaO}$ fly ash is better than low $\mathrm{CaO}$ fly ash in term of carbonation resistance, especially in high $\mathrm{CO}_{2}$ environment. The high $\mathrm{CaO}$ fly ash produced higher amount of calcium hydroxide $(\mathrm{CH})$ and lower total permeable void (at 28 days) than low $\mathrm{CaO}$ fly ash mixture. According to the results of thermogravimetric analysis (see Table 7), the FAM mixture has higher amount of $\mathrm{CH}$ (at 7 days) than FAB and FAH3 mixtures. Therefore, FAM (high $\mathrm{CaO}$ fly ash) mixture exhibited lower carbonation depth than the FAB (low $\mathrm{CaO}$ fly ash) (see Figure 15). However, FAH3 which is a low $\mathrm{CaO}$ fly ash has the lowest carbonation depth among all the studied fly ash mixtures. This is mainly due to a low porosity of the FAH3 mixture. The total porosity test results tested according to ASTM C642 [30] are shown in Table 7. The results show that the FAH3 mixture possesses the minimum total porosity ( 7 days water cured) followed by OPC, FAB and FAM mixtures.

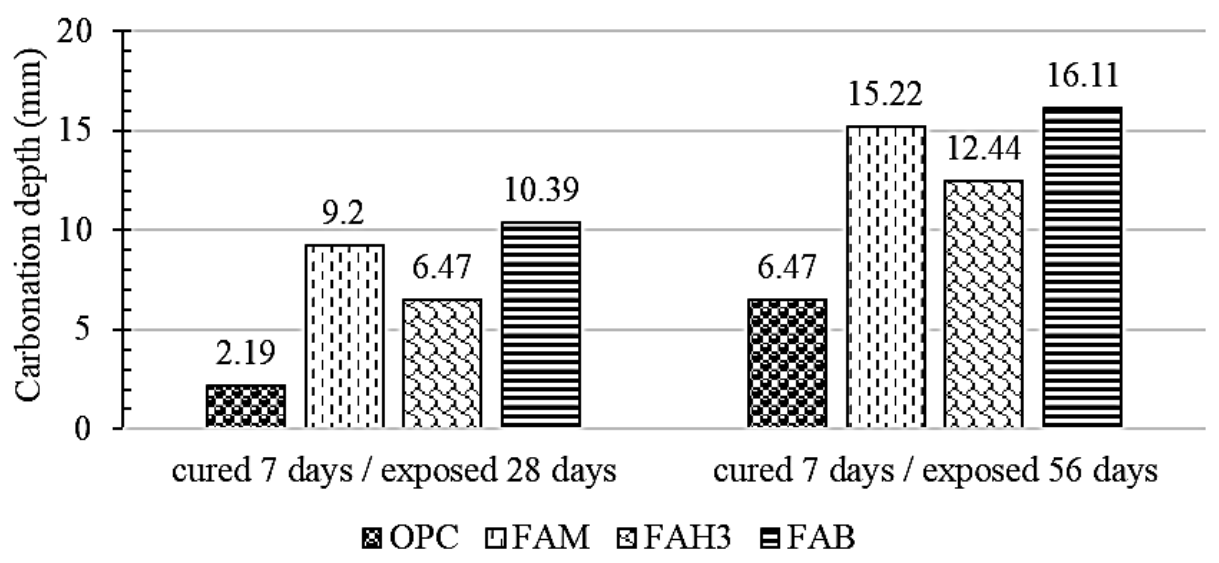

Figure 15: Carbonation depth of the tested mortars

Table 7. Porosity and Calcium Hydroxide (CH) Content at 7 days of the Tested Mortars

\begin{tabular}{ccc}
\hline Sample & Total Porosity (\%) & CH (\%) \\
\hline OPC & 16.02 & 21.14 \\
FAM & 17.44 & 16.41 \\
FAH3 & 15.88 & 14.34 \\
FAB & 16.41 & 14.72 \\
\hline
\end{tabular}


The $\mathrm{H}_{2} \mathrm{SO}_{4}$ acid resistance results in Figure 16 show that the OPC mixture has the highest mass loss in $\mathrm{H}_{2} \mathrm{SO}_{4}$ solution, followed by FAM, FAH3 and FAB mixtures. The calcium to silica ratios $\left(\mathrm{CaO} / \mathrm{SiO}_{2}\right)$ of the mixtures were calculated and their values are shown in Table 8 . The $\mathrm{CaO} / \mathrm{SiO}_{2}$ ratio was calculated from chemical composition of all binders in the tested mixtures as shown in the following equation:

$$
\frac{\mathrm{CaO}}{\mathrm{SiO}_{2}}=\frac{\left(\mathrm{CaO}_{c} \times \mathrm{W}_{c}\right)+\left(\mathrm{CaO}_{f} \times \mathrm{W}_{f}\right)}{\left(\mathrm{SiO}_{2 c} \times \mathrm{W}_{c}\right)+\left(\mathrm{SiO}_{2 f} \times \mathrm{W}_{f}\right)}
$$

Where, $\mathrm{CaO}_{c}=\mathrm{CaO}$ content in the cement $(\%)$

$\mathrm{CaO}_{f}=\mathrm{CaO}$ content in the fly ash $(\%)$

$\mathrm{SiO}_{2 c}=\mathrm{SiO}_{2}$ content in the cement $(\%)$

$\mathrm{SiO}_{2 f}=\mathrm{SiO}_{2}$ content in the fly ash $(\%)$

$\mathrm{W}_{c}=$ Unit weight of cement in the mixture $\left(\mathrm{kg} / \mathrm{m}^{3}\right)$

$\mathrm{W}_{f}=$ Unit weight of fly ash in the mixture $\left(\mathrm{kg} / \mathrm{m}^{3}\right)$

It can be seen that the mass losses of mortar samples (See Figure 16) have good correlation with $\mathrm{CaO} / \mathrm{SiO}_{2}$ ratios of the mixtures (see Table 8). The mixtures that have higher $\mathrm{CaO} / \mathrm{SiO}_{2}$ ratios tend to lose weight in $\mathrm{H}_{2} \mathrm{SO}_{4}$ acid easier than those with low $\mathrm{CaO} / \mathrm{SiO}_{2}$ ratios. This is because compounds with high $\mathrm{SiO}_{2}$ content are more resistant to sulfuric acid than those with high $\mathrm{CaO}$ content [31].

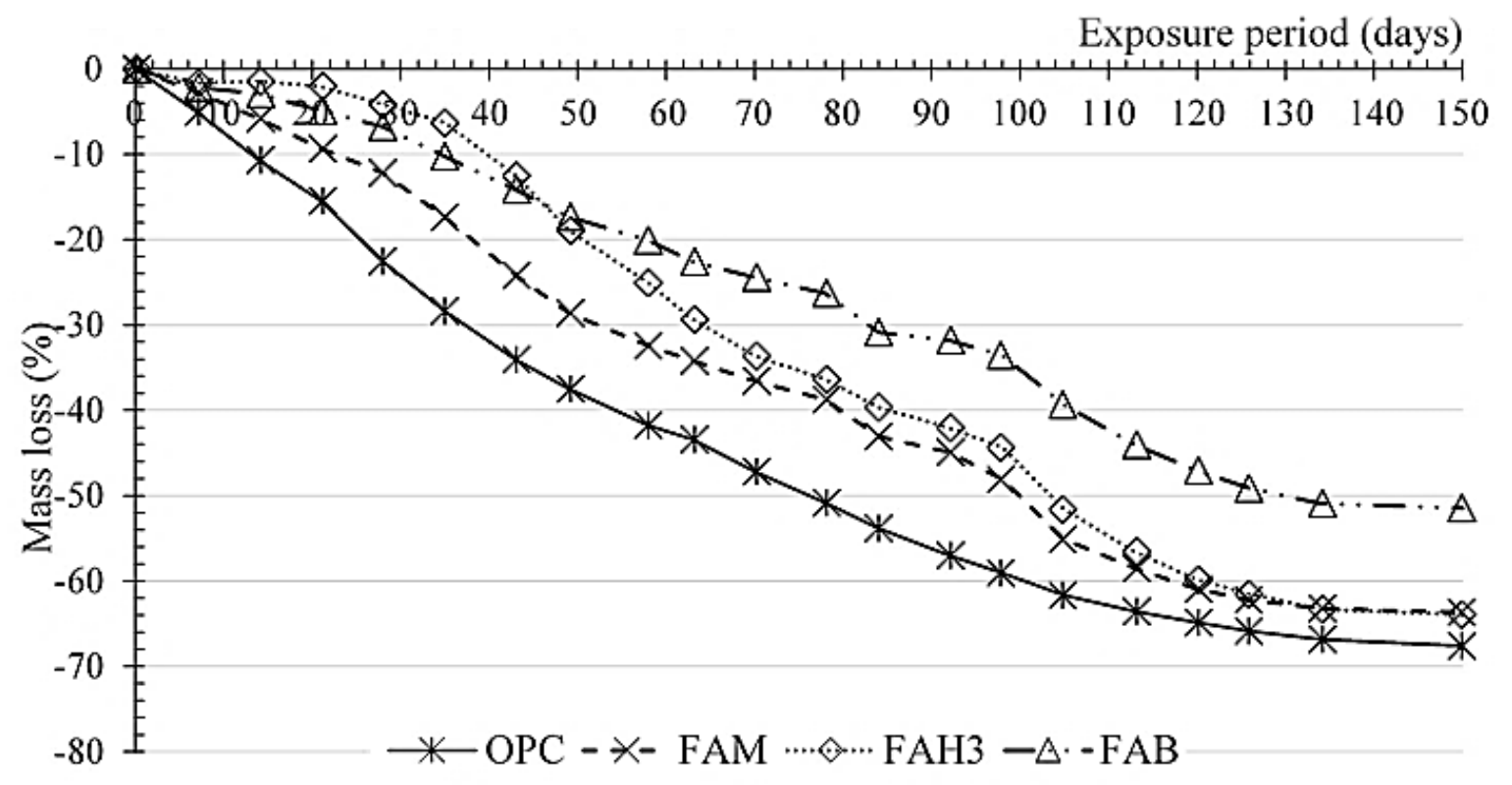

Figure 16. Mass losses in $\mathrm{H}_{2} \mathrm{SO}_{4}$ acid of the tested mixtures

Table 8. Relation of $\mathrm{CaO} / \mathrm{SiO}_{2}$ Ratio

\begin{tabular}{cccc}
\hline Samples & $\mathbf{C a O}(\%)$ & $\mathbf{S i O}_{2}(\%)$ & $\mathbf{C a O}_{\mathbf{O}} \mathbf{\%} \mathbf{S O}_{2}$ \\
\hline OPC & 64.80 & 19.7 & 3.29 \\
FAM & 20.76 & 34.5 & 2.14 \\
FAB & 2.55 & 64.45 & 1.39 \\
FAH3 & 5.85 & 48.68 & 1.66 \\
\hline
\end{tabular}


The RCP and chloride distribution results in Figures 17 and 18 show the same tendency that the mixture with the highest chloride penetration resistance is FAH3, which is followed by FAB, FAM and OPC. From the results, it can be seen that all fly ash mixtures are better than the OPC mixture. The chloride penetration results of fly ash mixtures get along well with the total porosity test results in Table 7, showing that lower porosity leads to better chloride resistance. The results also correspond with the study of Rerkhora et al. [32] which shows that low $\mathrm{CaO}$ fly ash has better chloride resistance than high $\mathrm{CaO}$ fly ash. From the experimental results, FAH3 is categorized in low and very low chloride penetrability according to ASTM C1202 [18] (see Table 9).

Table 9. Chloride Ion Penetrability Based on Charge Passed (ASTM C1202) [18]

\begin{tabular}{ll}
\hline Charge Passed (Coulombs) & Chloride Ion Penetrability \\
\hline$>4,000$ & High \\
$2,000-4,000$ & Moderate \\
$1,000-2,000$ & Low \\
$100-1,000$ & Very low \\
$<100$ & Negligible \\
\hline
\end{tabular}

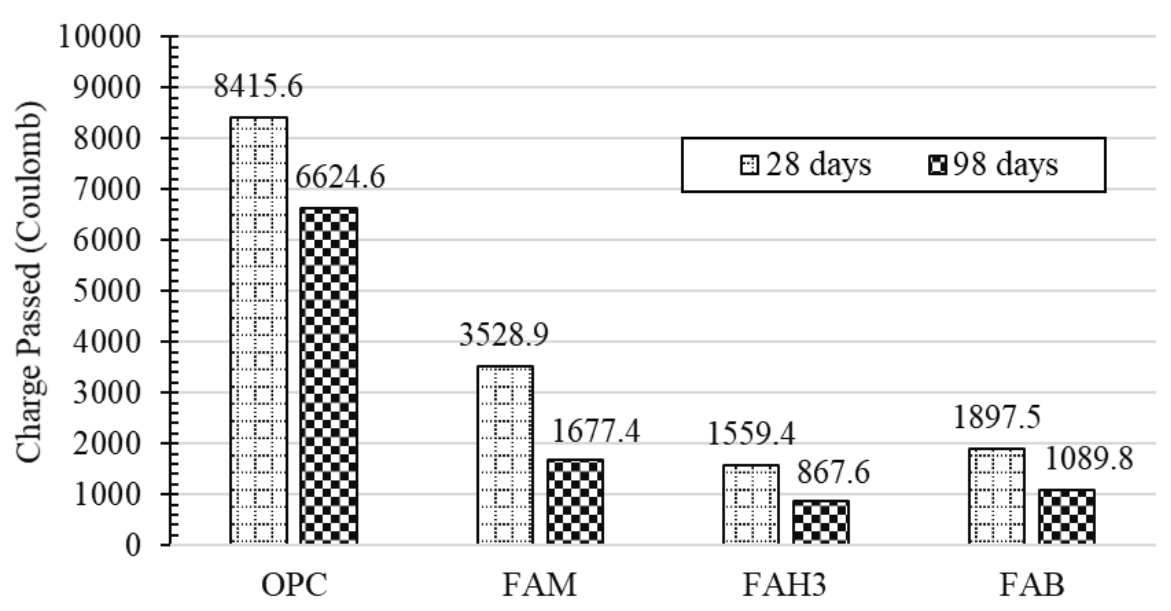

Figure 17. RCPT results of the tested concrete mixtures

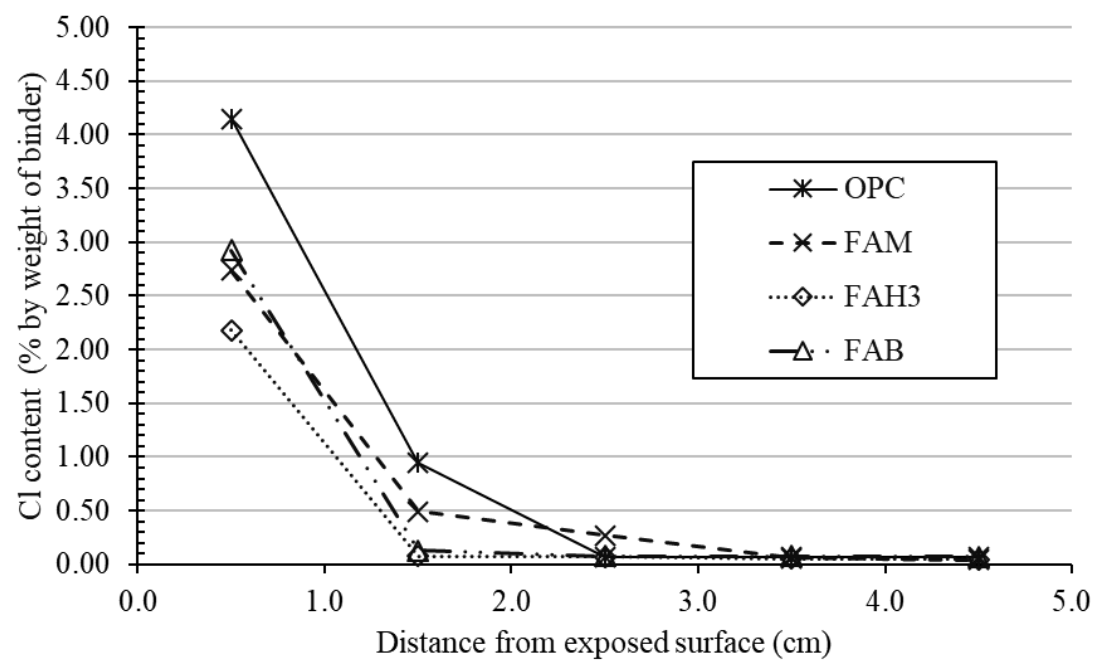

Figure 18. Chloride distribution of the tested concrete samples after exposure to a $5 \%$ chloride solution at 28 days 


\section{Conclusions}

A series of experiments were carried out to investigate various characteristics of three fly ashes and their effects on concrete. Based on the test results, the following conclusions are drawn:

- Hongsa fly ash (FAH3) contains lower LOI than FAB and FAM. On the other hand, amounts of $\mathrm{SiO}_{2}, \mathrm{Al}_{2} \mathrm{O}_{3}$ and amorphous content are found to be relatively high.

- Majority of FAH3 particles are non-spherical in shape with coarse cavities, making them porous and have high Blaine fineness, even though it has large particle size.

- Normal consistency and water requirement of FAH3 are observed to be higher than OPC, FAM and FAB, which is due mainly to its porous properties and nonspherical particles.

- FAH3 shows the longest setting time, maximum slump retention and highest chloride resistance, when compared to OPC, FAB and FAM.

- All fly ash mixtures exhibit lower total shrinkage when compared to OPC mixture. Further, the highest compressive strength and carbonation resistance is observed in FAH3 mixture when compared with FAM and FAB mixtures.

- The low semi-adiabatic temperature of mixture with FAH3 demonstrates its potential for being used in mass concrete.

- The $\mathrm{H}_{2} \mathrm{SO}_{4}$ acid resistance of all fly ash mixtures is better than that of OPC mixture due to lower $\mathrm{CaO} / \mathrm{SiO}_{2}$ ratios of the fly ash mixtures.

\section{Acknowledgement}

This research was supported by Lao Holding State Enterprise, the Center of Excellence in Material Science, Construction and Maintenance Technology, Thammasat University as well as TU Scholarship for Foreign Students to the first author.

\section{References}

[1] Hongsa Power Company Limited (HPC), "Fly Ash Sales to Flow from Lignite Plant," 2011 [Online]. Available:

http://www.hongsapower.com/index.php?model=cms\&view=news_page\&layout=new spage \&id=40\#ad-image- 0 [Accessed: May 2017]

[2] K. Sideris, H. Justnes, M. Soutsos, and T. Sui, "Fly ash," In "Properties of Fresh and Hardened Concrete Containing Supplementary Cementitious Materials," N.D. Belie, M. Soutsos, and E. Gruyaert, eds.: [e-book], 2018, [Online]. Available: https://link.springer.com/chapter/10.1007\%2F978-3-319-70606-1_2

[3] Headwaters Resources, "About Fly Ash," 2013. [Online]. Available: http://www. flyash.com/about-fly-ash/ [Accessed: May 2017]

[4] R. Siddique, and M.I. Khan, "Supplementary Cementing Materials," [e-book], 2011, doi: 10.1007/978-3-642-17866-5

[5] Thai Industrial Standards Institute (TISI), Coal Fly Ash for Use as an Admixture in Concrete (TIS 2135), Bangkok, Thailand, 2002.

[6] Annual Book of ASTM Standards, Standard Specification for Fly Ash and Row or Calcined Natural Pozzolan for use as a mineral admixture in Portland Cement Concrete (ASTM C618), West Conshohocken, United States, 2003.

[7] Annual Book of ASTM Standards, Standard Specification for Concrete Aggregate (ASTM C33), West Conshohocken, United States, 2003. 
[8] Annual Book of ASTM Standards, Standard Test Method for Normal Consistency of Hydraulic Cement (ASTM C187), West Conshohocken, United States, 1998.

[9] Annual Book of ASTM Standards, Standard Test Method for Time of Setting of Hydraulic Cement by Vicat needle (ASTM C191), West Conshohocken, United States, 2004.

[10] Annual Book of ASTM Standards, Standard Test Method for Sampling and Testing Fly Ash or Natural Pozzolans for Use in Portland-cement Concrete (ASTM C311), West Conshohocken, United States, 2004.

[11] American Concrete Institute (ACI), Standard Practice for Selecting Proportions for Normal, Heavyweight, and Mass Concrete (ACI 211.1), Farmington Hills, Michigan, United States, 2002.

[12] American Concrete Institute (ACI), Use of Fly Ash in Concrete (ACI 232.2R), Farmington Hills, Michigan, United States, 2003.

[13] K. Kawai, S. Yamaji, and T. Shinmi, "Concrete deterioration caused by sulfuric acid attack," Paper presented at 10DBMC International Conference on Durability of Building Materials and Components, Lyon, France, 2005.

[14] Annual Book of ASTM Standards, Standard Test Method for Slump of HydraulicCement Concrete (ASTM C143), West Conshohocken, United States, 2010.

[15] Annual Book of ASTM Standards, Standard Test Method for Compressive Strength of Cylindrical Concrete Specimens (ASTM C39), West Conshohocken, United States, 2018.

[16] T. Viet, R. Sahamitmongkol, and S. Tangtermsirikul, "Effect of pozzolanic materials on thermal properties and compressive strength of hardened mortar and concrete," In S. Tangtermsirikul (Chair), The Sixth Asia-Pacific Young Researchers and Graduates Symposium, Symposium conducted at SIIT, Thammasat University, Thailand, pp. 97102, August, 2014.

[17] Annual Book of ASTM Standards, Standard Test Method for Length Change of Hardened Hydraulic-Cement Mortar and Concrete (ASTM C157), West Conshohocken, United States, 2008.

[18] Annual Book of ASTM Standards, Standard Test Method for Electrical Indication of Concrete's Ability to Resist Chloride Ion Penetration ${ }^{1}$ (ASTM C1202-97), West Conshohocken, United States, 1997.

[19] Annual Book of ASTM Standards, Standard Test Method for Acid-Soluble Chloride in Mortar and Concrete ${ }^{1}$ (ASTM C1152), West Conshohocken, United States, 2003.

[20] K. Kaewmanee, P. Krammart, T. Sumranwanich, P. Choktaweekarn, and S. Tangtermsirikul, "Effect of free lime content on properties of cement-fly ash mixtures," Construction and Building Materials, Vol. 38, pp. 829-836, 2013.

[21] I. Sirisawat, W. Saengsoy, L. Baingam, P. Krammart, and S. Tangtermsirikul, "Durability and testing of mortar with interground fly ash and limestone cements in sulfate solutions," Construction and Building Materials, Vol. 64, pp. 39-46, 2014 [Online]. Available: https://doi.org/10.1016/j.conbuildmat.2014.04.083

[22] K.D. Weerdt, M.B. Haha, G.L. Saout, K.O. Kjellsen, H. Justnes, and B. Lothenbach, "Hydration mechanisms of ternary Portland cements containing limestone powder and fly ash," Cement and Concrete Research, Vol. 41, No. 3, pp. 279-291, 2011.

[23] T.B.T. Nguyen, R. Chatchawan , W. Saengsoy, S. Tangtermsirikul, and T. Sugiyama, "Influences of different types of fly ash and confinement on performances of expansive mortars and concretes," Construction and Building Materials, Vol. 209, pp. 176-186, 2019.

[24] A. Nawaz, P. Julnipitawong, P. Krammart, and S. Tangtermsirikul, "Effect and limitation of free lime content in cement-fly ash mixtures," Construction and Building Materials, Vol. 102, pp. 515-530, 2016. 
[25] L.E.R.D. Miron, and D. Koleva, eds., Concrete Durability: Cementitious Materials and Reinforced Concrete Properties, Behavior and Corrosion Resistance, $1^{\text {st }}$ Edition, Springer International Publishing, Cham, Switzerland, 2017.

[26] M. Tokyay, "Effects of three Turkish fly ashes on the heat of hydration of PC-FA paste" Cement and Concrete Research. Vol. 18, No. 6, pp. 957-960, 1988.

[27]R. Chatchawan, Use of Fly Ash to Enhance Performance of Expansive Concrete, Unpublished Master's Thesis, Sirindhorn International Institute of Technology, Thammasat University, Pathum Thani, Thailand, 2017.

[28] S. Tongaroonsri, and S. Tangtermsirikul, "Effect of mineral admixtures and curing periods on shrinkage and cracking age under restrained condition drying," Construction and Building Materials, Vol. 23, pp. 1050-1056, 2009.

[29] J. Khunthongkeaw, S. Tangtermsirikul, and T. Leelawat, "A study on carbonation depth prediction for fly ash concrete," Construction and Building Materials, Vol. 20, No. 9, pp. 744-753, 2006.

[30] Annual Book of ASTM Standard, Standard Test Method for Density, Absorption, and Voids in Hardened Concrete ${ }^{1}$ (ASTM C642), West Conshohocken, United States, 1997.

[31] W. Kunther, B. Lothenbach, and J. Skibsted, "Influence of the Ca/Si ratio of the C-S-H phase on the interaction with sulfate ions and its impact on the ettringite crystallization pressure," Cement and Concrete Research, Vol. 69, pp. 37-49, 2015.

[32] S. Rerkhora, T. Sumranwanich, W. Saengsoy, and S. Tangtermsirikul, "Effect of lignite fly ash and bituminous fly ash on chloride penetration resistance and chloride threshold content of concrete and depassivation time of reinforcing steel," Paper presented at The $8^{\text {th }}$ Annual Concrete Conference, Pattaya, Chonburi, Thailand, October 2012. 